\title{
A New Selective Medium for the Recovery and Enumeration of Monilinia fructicola, M. fructigena, and M. laxa from Stone Fruits
}

\author{
Achour Amiri, Imre J. Holb, and Guido Schnabel
}

First and third authors: Department of Entomology, Soils, and Plant Sciences, Clemson University, Clemson, SC 29634; second author: University of Debrecen, Centre for Agricultural Sciences and Engineering P.O. Box 36, H-4015 Debrecen, Hungary \& Plant Protection Institute, Hungarian Academy of Sciences, P.O. Box 102, H-1525 Budapest, Hungary.

Accepted for publication 12 June 2009.

\begin{abstract}
Amiri, A., Holb, I. J., and Schnabel, G. 2009. A new selective medium for the recovery and enumeration of Monilinia fructicola, $M$. fructigena, and M. laxa from stone fruits. Phytopathology 99:1199-1208.

Isolation of Monilinia spp. from stone and pome fruit surfaces is difficult due to the presence of several fast-growing fungal species such as Rhizopus, Alternaria, and Penicillium spp. Therefore, a new selective medium (acidified potato dextrose agar [pH 3.6] amended with fosetylaluminum [fosetyl-AL] at $500 \mu \mathrm{g} / \mathrm{ml}$ ) (APDA-F500) was developed for the recovery of Monilinia propagules. The antifungal agents fosetyl-Al, dichloran, ammonium molybdate, and 2-deoxy-D-glucose (2-dD-glucose) were tested in potato dextrose agar (PDA) for their selective activity against Monilinia fructicola and seven common fungal contaminants of peach, including Alternaria alternata, Aspergillus niger, Colletotrichum acutatum, Gilbertella persicaria, Penicillium expansum, Phomopsis amygdali, and Rhizopus stolonifer. Dichloran, ammonium molybdate, and 2-dD-glucose inhibited spore germination and mycelial growth of all test fungi, including $M$. fructicola, at comparable levels. Fosetyl-Al added to PDA (PDA-F) at 500 or $1,000 \mu \mathrm{g} / \mathrm{ml}$ did not inhibit germination of any of the fungi but had a strong effect on mycelial growth of six of eight test fungi at $1,000 \mu \mathrm{g} / \mathrm{ml}$, with the exceptions being $R$. stolonifer and $M$.

fructicola. Germination and mycelial growth of M. fructicola were least affected on APDA-F500 compared with the other test fungi. On APDAF500 at $\mathrm{pH} 3.2$ and 3.6, germination of $M$. fructicola was not inhibited but mycelial growth was reduced by 54.2 and $24.2 \%$, respectively. In all, $17 \mathrm{M}$. fructicola, $6 \mathrm{M}$. fructigena, and $6 \mathrm{M}$. laxa isolates collected from different geographic locations and diverse hosts were evaluated for their germination and mycelial growth on APDA-F500 (at pH 3.6). Germination was not inhibited for any isolate and relative mycelial growth was 45.8 to $83.3 \%$. Field-grown peach fruit from South Carolina and Hungary and plum fruit from Hungary were used to test the selectivity of APDAF500 for the recovery of three Monilinia spp. compared with PDA-F500 and Monilinia selective medium (MSM) previously developed for Monilinia spp. detection. Percent recovery of M. fructicola from South Carolinian peach fruit was highest on APDA-F500 (0, 17, and 69\% in June, July, and August, respectively) compared with PDA-F500 (0, 3.5, and $50 \%$, respectively) and MSM (0, 0 , and $6.8 \%$, respectively). Moreover, APDA-F500 selectively recovered $M$. fructigena and M. laxa propagules from the surfaces of Hungarian peach and plum fruit. Our results indicate that APDA-F500 is a useful medium for selective isolation and enumeration of the three most common Monilinia spp. attacking stone fruits worldwide.
\end{abstract}

Monilinia spp. are widespread fungal plant pathogens that cause extensive damage on members of the Rosaceae family, including important agricultural crops such as pome and stone fruits. Monilinia fructicola, $M$. fructigena, and $M$. laxa are the most common species within this genus (26). M. fructicola is most prevalent in North and South America $(7,35,40,45)$ and has recently emerged in several European countries $(9,13,48)$. In Spain and Italy, the two major countries producing stone fruits in Europe, M. laxa and M. fructigena are the most important cause of postharvest brown rot in peach and nectarine $(36,54)$. Monilinia spp. commonly infect blossoms, twigs, and fruit, causing blossom blight, twig blight, and fruit brown rot, respectively. Conidia of the fungus overwinter in fruit mummies or cankerous lesions $(10,35)$ serve as a primary inoculum source and cause blossom blight in the spring. Under unfavorable climatic conditions, infections remain latent in immature fruit until conditions become favorable for disease development later in the season $(8,16,21)$.

The recovery and isolation of plant pathogens enables scientists to study the genotypic and phenotypic diversity and the dynamics

\section{Corresponding author: G. Schnabel; E-mail address: schnabe@clemson.edu}

* The $\boldsymbol{e}$-Xtra logo stands for "electronic extra" and indicates that Figures 2 and 4 appear in color online.

doi:10.1094/PHYTO-99-10-1199

(C) 2009 The American Phytopathological Society of pathogen populations (4). However, the presence of bacterial, yeast, and several other fungal contaminants can make such efforts difficult. In one investigation dedicated to study the diversity of Monilinia spp. and the fungal microflora of stone fruit mummies in California orchards, more than 20 fungal genera were isolated (27). Penicillium, Cladosporium, Mucor, and Rhizopus spp. were most frequently isolated, while the recovery of Monilinia spp. was $<4 \%$. In respect to $M$. fructicola, the recovery of isolates can be especially challenging in dry years when isolations have to be performed on asymptomatic fruit. This is well documented by a study conducted by Emery et al. (16), where the incidence of latent infections of $M$. fructicola on commercially grown peach fruit varied between 0.4 and $22 \%$.

The use of a selective medium can greatly facilitate isolation attempts. Selective media have been developed for the isolation of fungal plant pathogens such as Botrytis spp. (14,32), Fusarium spp. (53), Alternaria spp. (28), and others. The only medium available for isolation of Monilinia spp. (Monilinia selective medium [MSM]) was developed $>30$ years ago by Phillips and Harvey (49). MSM consists of peach juice, streptomycin, and neomycin to limit the development of bacteria and pentachloronitrobenzene (PCNB) at $1,000 \mu \mathrm{g} / \mathrm{ml}$ to limit the growth of other fungal contaminants of peach fruit. The MSM medium has not been particularly selective for $M$. fructicola (49) and requires a 5- to 7-day incubation period (49). One reason for the weak selectivity of MSM might be related to the limited antifungal activity of PCNB, as reported for Penicillium spp. (19), Fusarium 
spp. $(43,53)$, and Epicoccum spp. (55). Furthermore, PCNB is undesirable as a constituent of media because of its carcinogenicity $(17,42)$.

The development of an efficient Monilinia spp.-selective medium is useful to study aspects of the ecology and biodiversity of Monilinia spp., which may ultimately lead to improved disease management practices. The goal of this study was to develop an efficient selective medium for Monilinia spp. Specific objectives were to (i) screen for active ingredients that selectively support germination and mycelial growth of $M$. fructicola, M. laxa, and M. fructigena; (ii) investigate their inhibitory activity against several potential fungal peach contaminants; and (iii) determine the ability of the newly developed medium for Monilinia spp. recovery from asymptomatic stone fruits.

\section{MATERIALS AND METHODS}

Fungal isolates and inoculum production. Forty-three isolates of fungal opportunists or pathogens of peach fruit, including Alternaria alternata, Aspergillus niger, Colletotrichum acutatum, Gilbertella persicaria, M. fructicola, M. fructigena, M. laxa, Phomopsis amygdali, Penicillium expansum, and Rhizopus stolonifer were used in this study (Table 1). Isolates were stored at $-80^{\circ} \mathrm{C}$ on silica gel (grade 40; Sigma-Aldrich, St. Louis) and new cultures were grown from this stock on potato dextrose agar (PDA) medium (EMD Chemicals Inc., Gibbstown, NJ) for each experiment. Conidia of Monilinia spp. and Alternaria alternata isolates were produced on V8 agar and acidified PDA (APDA; $\mathrm{pH}$ 4.2 ), respectively. Conidia from the remaining isolates were obtained on PDA medium incubated at $22^{\circ} \mathrm{C}$ for 3 to 4 days, with the exception of $C$. acutatum and Phomopsis amygdali isolates, which had to be stimulated for sporulation by keeping cultures in the dark for 7 days before exposure to a 12-h photoperiod for 10 to 15 days. For each experimental run, conidia were freshly harvested and resuspended in $10 \mathrm{ml}$ of sterile distilled water containing $0.05 \%$ Tween 80 . Conidia were filtered through cheesecloth and the final concentration was determined using a hemacytometer.

Fungicides and media recipes. Four active ingredients (a.i), including dichloran (Botran 75WP; Gowan Company, Yuma, AZ), ammonium molybdate tetrahydrate (ammonium molybdate; EMD Chemical Inc.), 2-desoxy-D-glucose (2-dD-glucose) (grade II, 98\%; Sigma-Aldrich), and fosetyl-Aluminum (fosetyl-Al) (Aliette WDG; Bayer Crop Science, Research Triangle Park, NC), were evaluated for their effect on germination and mycelial growth of the test fungi. These active ingredients were chosen because antifungal effects against common peach pathogens were reported previously. For example, dichloran was shown to inhibit $R$. sto-

TABLE 1. Characteristics of fungal isolates used in this study

\begin{tabular}{|c|c|c|c|c|}
\hline Fungal species & Isolate name & Geographic origin (region, country) & Host & Year of isolation \\
\hline \multirow[t]{14}{*}{ Monilinia fructicola } & Mf.Pdt11 & South Carolina, United States & Peach & 2007 \\
\hline & Mf.DMap4 & South Carolina, United States & Peach & 2008 \\
\hline & Mf.Egpc5 & South Carolina, United States & Peach & 2007 \\
\hline & Mf.Bmpc9a & Georgia, United States & Peach & 2006 \\
\hline & Mf.Bpc1 & Georgia, United States & Peach & 2007 \\
\hline & Mf.Bpc8 & Georgia, United States & Peach & 2007 \\
\hline & Mf.SLf8 & Georgia, United States & Peach & 2008 \\
\hline & NJ08 & New Jersey, United States & Peach & 2006 \\
\hline & NJ012 & New Jersey, United States & Nectarine & 2006 \\
\hline & NJ015 & New Jersey, United States & Peach & 2006 \\
\hline & $2 \mathrm{~F}$ & New York, United States & Cherry & 2007 \\
\hline & $6 c$ & New York, United States & Cherry & 2007 \\
\hline & 10B & New York, United States & Cherry & 2007 \\
\hline & 13B & New York, United States & Cherry & 2007 \\
\hline & MFG.DP24 & Hajdú, Hungary & Apple & 2002 \\
\hline \multirow[t]{6}{*}{ Monilinia laxa } & ML.E14 & Szabolcs, Hungary & Cherry & 2000 \\
\hline & ML.D5 & Hajdú, Hungary & Plum & 2002 \\
\hline & ML.BP5 & Pest, Hungary & Cherry & 2001 \\
\hline & ML.ME6 & Borsod, Hungary & Peach & 2001 \\
\hline & ML.MA21 & Szabolcs, Hungary & Cherry & 2001 \\
\hline & ML.DP7 & Hajdú, Hungary & Plum & 2002 \\
\hline \multirow[t]{2}{*}{ Alternaria alternata } & Aa.by1 & Georgia, United States & Peach & 2006 \\
\hline & Aa.sc1 & South Carolina, United States & Peach & 2006 \\
\hline \multirow[t]{2}{*}{ Colletotrichum acutatum } & Ca.cca1 & Georgia, United States & Peach & 2006 \\
\hline & Ca.ca2 & South Carolina, United States & Peach & 2006 \\
\hline \multirow{2}{*}{ Phomopsis amygdali } & Pa.by1 & Georgia, United States & Peach & 2006 \\
\hline & Pa.eg1 & South Carolina, United States & Peach & 2006 \\
\hline
\end{tabular}

\footnotetext{
${ }^{a}$ Amiri et al. (3).
}

b Ma et al. (39). 
lonifer at $2.5 \mu \mathrm{g} / \mathrm{ml}$ and Aspergillus spp. and Penicillium spp. at $12.5 \mu \mathrm{g} / \mathrm{ml}(33) ; 2-\mathrm{dD}$-glucose was shown to reduce mycelial growth of $R$. stolonifer and Penicillium expansum at $1 \mu \mathrm{g} / \mathrm{ml}(15)$; ammonium molybdate at $10 \mathrm{mM}$ significantly reduced the incidence of Penicillium expansum and $R$. stolonifer in apple fruit (44); and fosetyl-Al was shown to be active against a range of fungi at concentrations ranging from 100 to $>2,000 \mu \mathrm{g} / \mathrm{ml}$ (18). All active ingredients were incorporated into autoclaved and cooled $\left(50^{\circ} \mathrm{C}\right)$ PDA used as basal medium after preliminary tests using several media (data not shown). Dichloran was added to PDA at final concentrations of 5,15 , and $25 \mu \mathrm{g} / \mathrm{ml}$; ammonium molybdate at $10^{3}, 5 \times 10^{3}$, and $10^{4} \mu \mathrm{g} / \mathrm{ml}$; fosetyl-Al at 500,750 , and $1,000 \mu \mathrm{g} / \mathrm{ml}$; and $2-\mathrm{dD}$-glucose at 1,2 , and $5 \mu \mathrm{g} / \mathrm{ml}$. The inhibitory effect of these four active ingredients incorporated into PDA was compared with MSM (49). The MSM medium consisted of 2\% agar (Acros Organics, Morris Plains, NJ) and 5\% peach juice obtained by mixing yellow cling canned peach halves (Great Value brand; Wal-Mart, Bentonville, AR) for $1 \mathrm{~min}$ in a blender. The mixture was autoclaved for $20 \mathrm{~min}$ and cooled to $50^{\circ} \mathrm{C}$ before adding PCNB $(99 \%)$ at $1,000 \mu \mathrm{g} / \mathrm{ml}$ pentachloronitrobenzene (Sigma-Aldrich) and streptomycin sulphate (Biosciences, Inc., La Jolla, CA) at 1,000 $\mu \mathrm{g} / \mathrm{ml}$. Fungicide-amended PDA and MSM media were poured into polystyrene petri dishes (90 $\mathrm{mm}$ in diameter) and dishes were stored at $4^{\circ} \mathrm{C}$ for up to 7 days.

Germination of $M$. fructicola and other test fungi on MSM and fungicide-amended PDA. A $100-\mu$ l spore suspension $\left(10^{5}\right.$ conidia/ml) volume from each isolate was spread evenly onto solidified media in petri dishes using a sterilized glass rod. Dishes were sealed with Parafilm (Pechiney Plastic Packaging, Menasha, WI) and incubated at $22^{\circ} \mathrm{C}$, and percent germination was determined after 24 and $72 \mathrm{~h}$. To calculate germination frequencies, each petri dish was divided into three sectors of comparable sizes with a marker and 100 spores per sector were examined under a microscope. A conidium was considered germinated when it had produced a germ tube two times longer than its diameter. Results were expressed as percent conidial inhibition relative to the control PDA. Three petri dish replicates were assessed for each treatment and the entire experiment was conducted twice.

Mycelial growth and sporulation of $M$. fructicola and other test fungi on MSM and fungicide-amended PDA. Plates containing the media were inoculated with mycelial plugs $(5 \mathrm{~mm}$ in diameter) taken from the advancing margins of 2- to 3-day-old Penicillium expansum, $R$. stolonifer, and $G$. persicaria colonies; 4- to 7-day-old M. fructicola, Alternaria alternata, and Aspergillus niger colonies; and 7- to 10-day-old C. acutatum and Phomopsis amygdali colonies. Five petri dishes were inoculated for each isolate-fungicide concentration combination. Dishes were sealed with parafilm and incubated at $22^{\circ} \mathrm{C}$ in the dark, and radial mycelial growth was measured after 48 and $96 \mathrm{~h}$. Percent growth inhibition on fungicide-amended PDA and MSM was calculated relative to the unamended PDA control. The entire experiment was conducted twice. Sporulation of each fungus was evaluated using the same petri dishes used for mycelial growth test. The percent sporulation of each isolate was scored using a scale from 0 to 4 , where $0=$ no sporulation, $1=1$ to $25,2=26$ to $50,3=51$ to $75 \%$, and $4=>75 \%$ sporulation expressed relative to the sporulation on the control dishes. Three petri dishes were assessed for each treatment and the entire experiment was conducted twice.

Effect of $\mathrm{pH}$ on the efficacy of fosetyl-Al on germination and mycelial growth of tested fungi. The effect of $\mathrm{pH}$ on fosetyl-Al activity against conidial germination and mycelial growth was investigated. Autoclaved PDA was cooled to $50^{\circ} \mathrm{C}$; acidified to $\mathrm{pH} 2.8,3.2,3.6,4.0$, or 5.2 using lactic acid (SigmaAldrich); and amended with fosetyl-Al at $500 \mu \mathrm{g} / \mathrm{ml}$, resulting in a medium designated APDA-F500. Nonacidified but fosetyl-Al- amended PDA was designated PDA-F500. Fosetyl-Al was tested at $500 \mu \mathrm{g} / \mathrm{ml}$ based upon results from mycelial growth and germination inhibition. The $\mathrm{pH}$ of the medium was verified using a pH meter (Acumet Basic AB15; Fisher Scientific, Fair Lawn, $\mathrm{NJ}$ ). Conidial germination and mycelial growth tests were conducted as described above and all experiments were conducted twice.

Germination and mycelial growth of Monilinia spp. from different geographic origins and hosts on APDA-F500. In total, 29 isolates (17 M. fructicola, $6 \mathrm{M}$. fructigena, and $6 \mathrm{M}$. laxa) were tested for germination and mycelial growth on APDA-F500. These isolates were collected from five states within the United States, including Georgia, South Carolina, New York, New Jersey, and California, and four counties in Hungary, including Hajdú, Szabolcs, Borsod, and Pest (Table 1). Isolates from South Carolina, Georgia, New Jersey, and California were collected from peach fruit, except for isolate NJ012 from New Jersey. Isolates from New York were obtained from cherry fruit. $M$. fructigena isolates were collected from apple (Hajdú, Szabolcs, Borsod, and Pest) and plum (Hajdú) fruits, while M. laxa isolates were collected from plum (Hajdú), cherry (Szabolcs and Pest), and peach (Borsod) fruits. Two isolates from each species were tested for germination: M. fructicola (isolates Mf.Bmpc9 and 139), $M$. fructigena (isolates MFG.E4 and MFG.D10), and M. laxa (isolates ML.E14 and ML.D5). All 29 isolates were tested for mycelial growth on APDA-F500. Germination and mycelial growth were evaluated on APDA-F500 ( $\mathrm{pH}$ 3.6) as described above. Three and five petri dish replicates were assessed for germination and mycelial growth, respectively, and the entire experiment was conducted twice.

Recovery of Monilinia propagules from peach and plum fruit surfaces. PDA-F500, APDA-F500, and MSM media were tested for their ability to recover $M$. fructicola propagules from freshly harvested peach fruit (cv. Redskin). On 6 June, 9 July, and 13 August 2007, 10 asymptomatic fruit of similar size $(\approx 4,7$, and $9 \mathrm{~cm}$ in diameter, respectively) were harvested at each evaluation time from the Musser Fruit Research Center in Seneca, SC. In addition, the ability of APDA-F500 medium to recover $M$. laxa and $M$. fructigena propagules from peach and plum fruit grown in Hungary was evaluated. Twenty asymptomatic plum (cv. Cacanska rodna) and 20 peach (cv. Cresthaven) fruits were harvested in the vicinity of Debrecen, Hungary on 16 and 29 August 2008, respectively. The fruit surface microflora was washed off within $48 \mathrm{~h}$ of harvest with $100 \mathrm{ml}$ of sterile water as described previously (2). A 100- $\mu$ l aliquot of each fruit wash was spread over PDA-F500, APDA-F500 ( $\mathrm{pH}$ 3.6), and MSM from peach fruit collected in South Carolina. Fruit washes from peach and plum fruit collected in Hungary were spread on APDA-F500. Three replicate petri dishes were inoculated for each fruit. Colonies of $M$. fructicola and other microorganisms were counted on each petri dish after 4 days of incubation at $22^{\circ} \mathrm{C}$ using a digital colony counter (Bel-Art Products, Pequannock, NJ). A conidial suspension of $M$. fructicola (isolate Mf.Bmpc9) at $10^{4}$ conidia/ml was spread on each media and used as a standard for $M$. fructicola identification. The washed fruit were peeled and the peels were arranged in a square format used to calculate the fruit surface. Colony counts were converted to conidia per square centimeter of peach or plum surface. Five colonies resembling $M$. fructicola, M. fructigena, or M. laxa and other most-observed fungal propagules growing on each media were randomly selected for identification. Colonies from one dish of each medium were transferred to new PDA dishes, grown for 5 to 7 days, and identified by amplifying and sequencing the ribosomal internal transcribed spacer (ITS) regions ITS 1 and ITS 2 as described previously (31).

Statistical analysis. All laboratory experiments were conducted twice and, because results from the two experimental runs were similar (variance between the two runs $\leq 0.05$ ), data were 
combined for analysis. Based on the five replicates from two experimental runs, data from conidial germination, sporulation, and mycelial growth inhibition experiments were expressed as percent relative to the control (PDA). Means and 95\% confidence intervals (CIs) were computed for statistical evaluation (11). No formal hypothesis test was carried out due to violation of underlying assumptions because several values were close to 100 or 0 . Number of colony counts of each microorganism on each medium

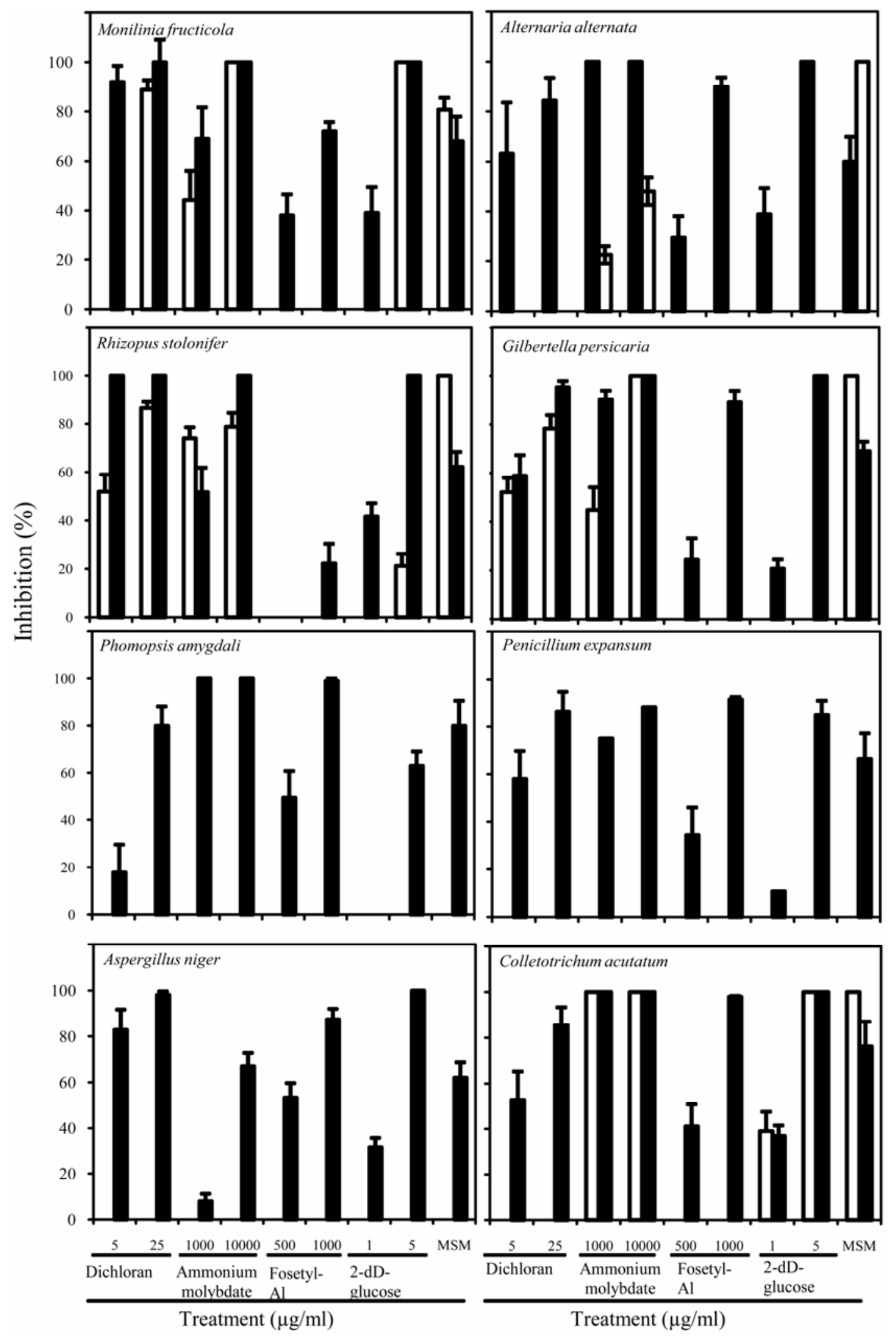

Fig. 1. Conidial germination (open bars) and mycelial growth (closed bars) inhibition of Monilinia fructicola and seven other fungal contaminants of peach fruit grown on Monilinia selective medium (MSM) and potato dextrose agar (PDA) amended with various active ingredients relative to unamended PDA after $72 \mathrm{~h}$ for germination and $96 \mathrm{~h}$ for mycelial growth at $22^{\circ} \mathrm{C}$. Data are the means (two isolates per species) of 18 and 10 replicates per media and active ingredient concentration across two experimental runs for spore germination and mycelial growth, respectively. Vertical bars indicate the standard deviations. 
was transformed to the number of colonies per square centimeter of fruit surface. Data from recovery tests of Monilinia spp. from peach and plum surfaces were examined using analysis of variance after the assumption of a normal distribution of errors was verified. Means were compared using the Newman-Keuls test. Analysis was performed using STATISTICA program (version 6.0; Statsoft, Inc.).

\section{RESULTS}

Germination and mycelial growth of test fungi on MSM and fungicide-amended PDA. All fungi tested germinated without inhibition on PDA after $24 \mathrm{~h}$. No or weak germination of C. acutatum, Phomopsis amygdali, Alternaria alternata, and $M$. fructicola was observed after $24 \mathrm{~h}$ of incubation regardless of the fungicide treatment (data not shown). Dichloran and ammonium molybdate had no germicidal effect on $P$. amygdali, Aspergillus niger, Penicillium expansum, and Alternaria alternata (dichloran only) after $72 \mathrm{~h}$ of incubation at $22^{\circ} \mathrm{C}$ (Fig. 1). These two compounds, applied at 25 and $10,000 \mu \mathrm{g} / \mathrm{ml}$, respectively, inhibited germination of $M$. fructicola (89 and 100\%), R. stolonifer (86.5 and $78.7 \%)$, G. persicaria (72.8 and 100\%), and C. acutatum (ammonium molybdate only, 100\%). All fungi germinated without inhibition on PDA amended with fosetyl-Al at 500 or $1,000 \mu \mathrm{g} / \mathrm{ml}$. Germination of M. fructicola and C. acutatum was completely inhibited by 2 -dD-glucose at $5 \mu \mathrm{g} / \mathrm{ml}$ but no effect was observed on the germination of the other fungi. Phomopsis amygdali, Aspergillus niger, and Penicillium expansum germinated $(100 \%)$ on MSM medium, whereas conidial germination of M. fructicola was $80.5 \%$ inhibited relative to nonamended PDA (Fig. 1).
In general, mycelial growth of isolates grown on ammonium molybdate-amended PDA and MSM was sparse and lacked uniformity. Growth inhibition data were also collected $48 \mathrm{~h}$ after inoculation but mycelial development of some test fungi was insufficient for data collection (data not shown). Dichloran, ammonium molybdate, and 2-dD-glucose added to PDA at the higher rate inhibited strongly mycelial growth of all eight fungal species. The average percent inhibition relative to nonamended PDA was 62.9 to $100 \%$ (Fig. 1). Dichloran inhibited mycelial growth of all test fungi at the lower rate $(5 \mu \mathrm{g} / \mathrm{ml})$ by $>50 \%$, with the exception of Phomopsis amygdali (17.8\%). Mycelial growth inhibition of all fungi tested was 52 to $100 \%$ at the lower rate $(1,000 \mu \mathrm{g} / \mathrm{ml})$ of ammonium molybdate, with the exception of $A$. niger (8\% inhibition). Dichloran and 2-dD-glucose completely inhibited $M$. fructicola mycelial growth at $5 \mu \mathrm{g} / \mathrm{ml}$. Among the four active ingredients tested, fosetyl-Al at 1,000 $\mu \mathrm{g} / \mathrm{ml}$ inhibited $R$. stolonifer and M. fructicola mycelium the least (72 and $22 \%$, respectively). The inhibition of mycelial growth of the eight fungi tested on fosetyl-Al-amended PDA at 500, 750, and 1,000 $\mu \mathrm{g} / \mathrm{ml}$ was 0.0 to $53.1,10.8$ to 91.1 (data not shown), and 22.2 to $99.0 \%$, respectively (Fig. 1). Mycelial growth of all eight test fungi was inhibited at a similar level on MSM medium, and the average percent inhibition ranged from $60 \%$ in Alternaria alternata, $R$. stolonifer, and Aspergillus niger to $67.6 \%$ in M. fructicola and $76.2 \%$ in C. acutatum (Fig. 1).

Sporulation of test fungi on MSM and fungicide-amended PDA. Overall, sporulation was reduced on MSM and on PDA amended with the higher concentration of all four active ingredients, with the exception of Phomopsis amygdali and Aspergillus niger on 2-dD-glucose-amended PDA (Table 2). In contrast to all other fungi tested, sporulation of $M$. fructicola was readily

TABLE 2. Relative sporulation of Monilinia fructicola and seven other fungal species on Monilinia selective medium (MSM) and on potato dextrose agar amended with different active ingredients

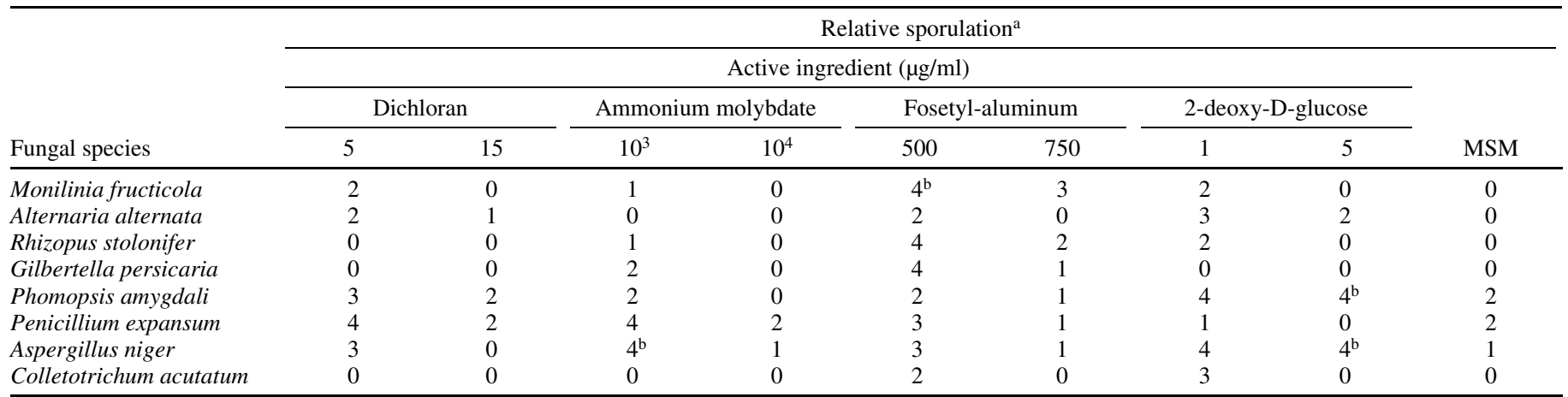

${ }^{a}$ Sporulation relative to potato dextrose agar (PDA). Data are the mean sporulation level of 12 replicates (from two isolates per species) per media and active ingredient concentration across two experimental runs after 4 days of incubation at $22^{\circ} \mathrm{C}$. Sporulation levels $0,1,2,3$, and 4 indicate no sporulation, $\leq 25,26$ to 50,51 to 75 , and $>76 \%$ sporulation, respectively, relative to the PDA control.

b Sporulation heavier than control.

TABLE 3. Effect of $\mathrm{pH}$ on the germination and mycelial growth of Monilinia fructicola and seven other fungal contaminants of peach fruit on acidified potato dextrose agar amended with fosetyl-aluminum (PDA-F) ${ }^{\mathrm{a}}$

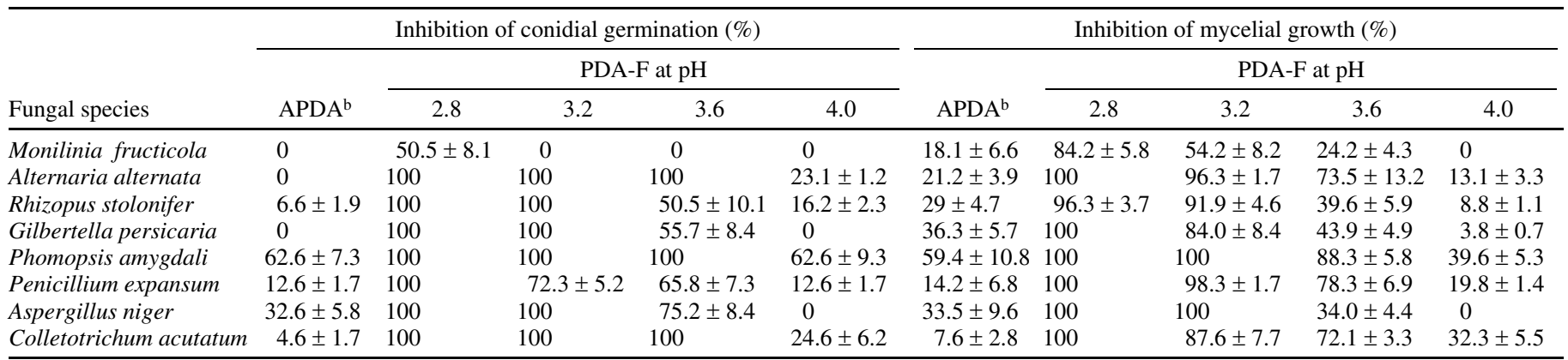

a Data are means $\pm 95 \%$ confidence intervals of 10 replicates (from two isolates per species) per media and $\mathrm{pH}$ value across two experimental runs.

b Acidified PDA (APDA) at $\mathrm{pH}$ 3.6. 
observed on PDA amended with fosetyl-Al at $750 \mu \mathrm{g} / \mathrm{ml}$ (Table 2). All other active ingredients completely inhibited sporulation of M. fructicola at the higher rates, including on MSM.

Effect of $\mathbf{p H}$ on the efficacy of fosetyl-Al. All fungi tested were strongly inhibited $(>90 \%)$ on unamended APDA medium at $\mathrm{pH}<3.2$ (data not shown). At $\mathrm{pH} 5.2$, all fungi, with the exception of Phomopsis amygdali, grew $>50 \%$. Consequently, only inhibition data from APDA at pH 3.6 are shown (Table 3). Unamended APDA medium at $\mathrm{pH} 3.6$ inhibited conidial germination of $C$. acutatum, $R$. stolonifer, Penicillium expansum, Aspergillus niger, and Phomopsis amygdali by 4.6, 6.6, 12.6, 32.6, and $62.6 \%$, respectively, whereas no inhibition of $M$. fructicola,
Alternaria alternata, and G. persicaria was observed on APDA (Table 3). The fungi tested were differentially inhibited on APDAF500. A strong inhibition $(>50 \%)$ of conidial germination of all fungi was observed on APDA-F500 medium at $\mathrm{pH} 3.6$, except $M$. fructicola $(0 \%)$ (Table 3$)$; complete germination inhibition was observed for Alternaria alternata, Phomopsis amygdali, and $C$. acutatum. At $\mathrm{pH} 3.2$, germination of all tested fungi was completely inhibited, with the exception of Penicillium expansum and $M$. fructicola (72.3 and $0 \%$ inhibition, respectively). $M$. fructicola was the only fungus able to germinate $(50.5 \%$ inhibition) on APDA-F500 at $\mathrm{pH} 2.8$. Even though germination of $R$. stolonifer and Penicillium expansum was not entirely inhibited

\section{A}

Monilinia fructicola

Phomopsis amygdali
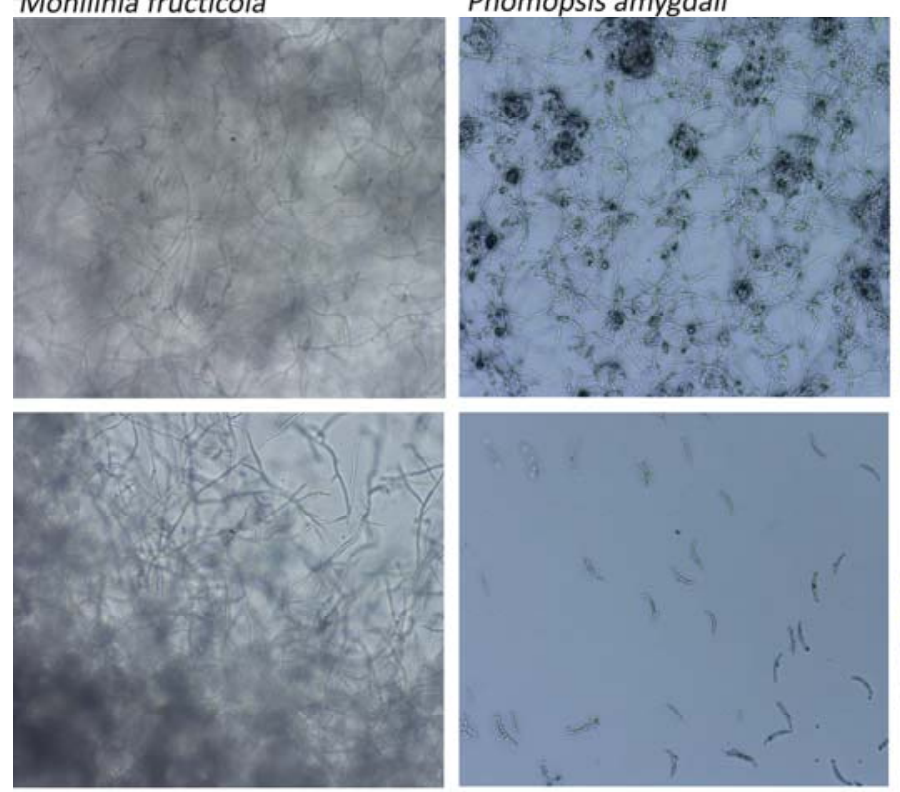

Rhizopus stolonifer
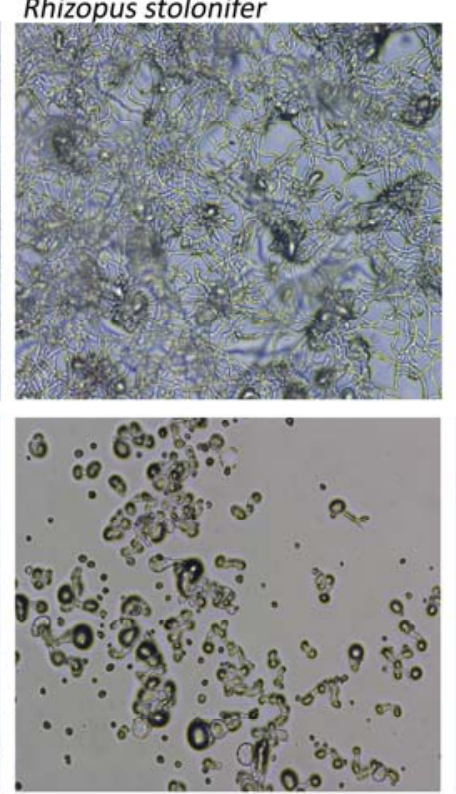

Penicillium expansum
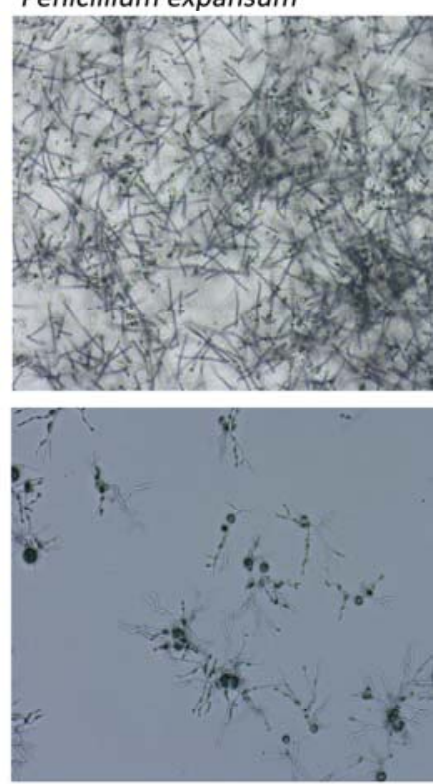

B
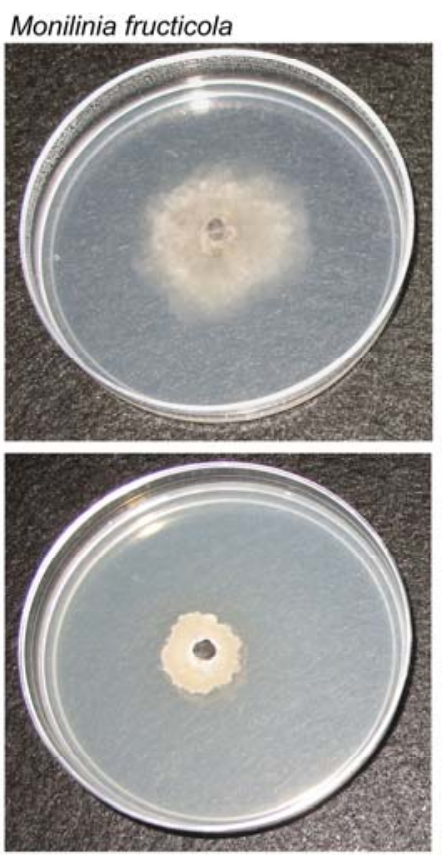

Phomopsis amygdali
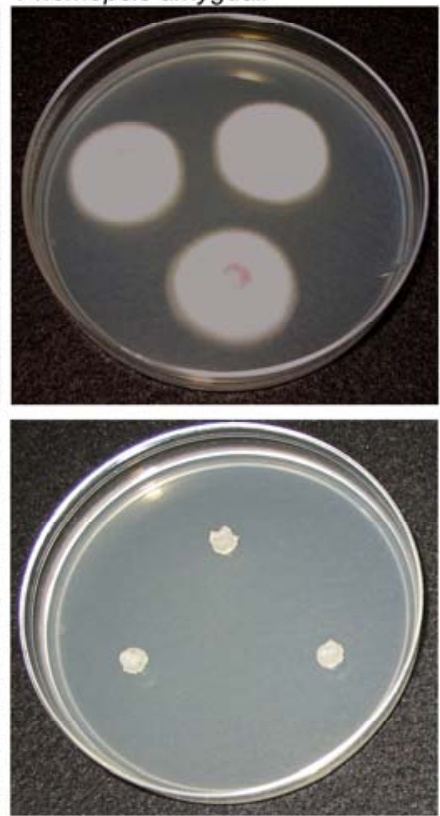

Rhizopus stolonifer
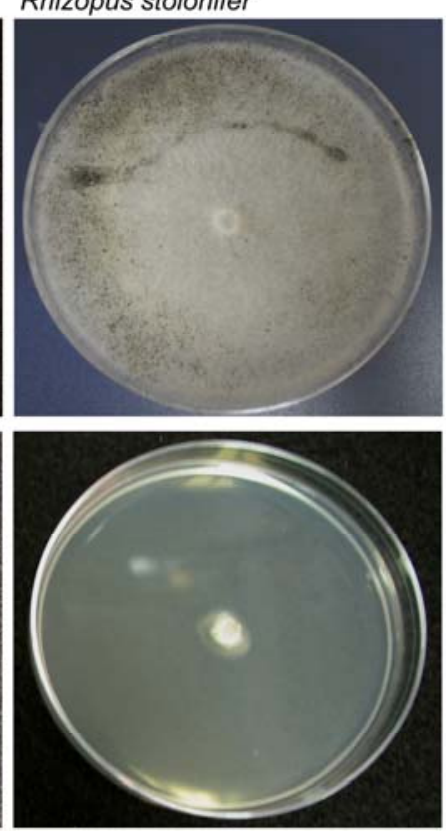

Penicillium expansum
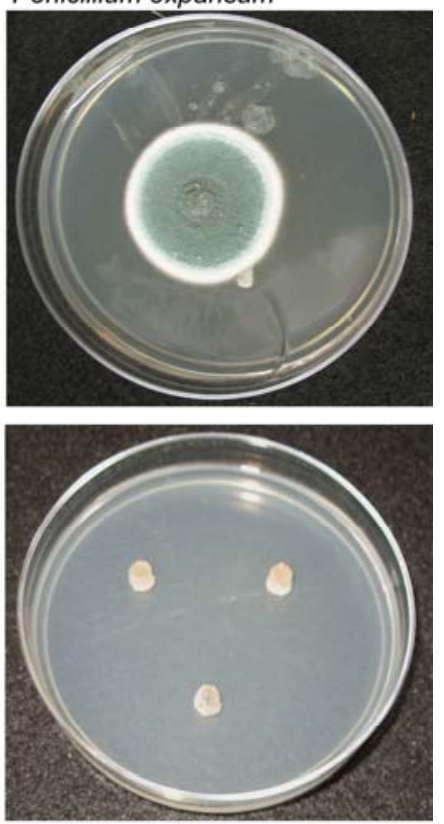

Fig. 2. Germination (A) and hyphal growth (B) of Monilinia fructicola, Phomopsis amygdali, Rhizopus stolonifer, and Penicillium expansum on potato dextrose agar (PDA) (first row) and acidified PDA amended with fosetyl-aluminum at $500 \mu \mathrm{g} / \mathrm{ml}$ (APDA-F500) at $\mathrm{pH} 3.6$ (second row) after $72 \mathrm{~h}$ of incubation at $22^{\circ} \mathrm{C}$. 
on APDA-F500 at $\mathrm{pH} 3.6$, the germ tube length was substantially reduced for $R$. stolonifer and, to a lesser degree, for Penicillium expansum compared with $M$. fructicola (Fig. 2A).

The average growth inhibition on unamended APDA at $\mathrm{pH} 3.6$ varied between $7.6 \%$ for C. acutatum and $59.7 \%$ for Phomopsis amygdali (Table 3). Mycelial growth of the fungi tested was reduced by lowering the $\mathrm{pH}$ of the PDA-F500 medium. At $\mathrm{pH} 2.8$, mycelial growth of most fungi was completely inhibited, with the exception of $M$. fructicola ( $84.2 \%$ inhibition) and $R$. stolonifer (96.3\% inhibition). Germ tube elongation of $M$. fructicola was less affected at $\mathrm{pH} 3.6$ compared with the other fungi tested (Fig. 2B).

Intraspecific variation in germination and mycelial growth of Monilinia spp. on APDA-F500. Germination of the three Monilinia spp. was not inhibited (100\% germination) on APDAF500 at pH 3.6 after $72 \mathrm{~h}$ (Fig. 3). Relative mycelial growth of $M$. fructicola, M. fructigena, and M. laxa isolates on APDA-F500 was 45.8 to $83.3,58.8$ to 80.4 , and 53.3 to $79.8 \%$, respectively, after $96 \mathrm{~h}$ of incubation (Table 4).

Recovery of Monilinia propagules from peach and plum fruit surfaces. No $M$. fructicola propagules were recovered on any of the media at the early (June) sampling date (Table 5). The recovery of $M$. fructicola was significantly higher $(P=0.03)$ on PDA-F500 and APDA-F500 compared with MSM at the July and August sampling dates. However, the number of contaminants (i.e., bacteria, yeast, and other fungi) was eight to nine times greater on PDA-F500 and MSM at the June and July sampling dates and two to three times higher at the August sampling date compared with APDA-F500 (Table 5). M. fructigena and M. laxa propagules were collected in August from peach and plum fruit collected in Hungary. The recovery of M. fructigena and M. laxa on APDA-F500 from peach was 64.3 and $4.2 \%$ and from plum was 56.2 and $3 \%$, respectively (Table 6).

Among fruit surface contaminants, Cladosporium spp. were recovered most frequently on APDA-F500 in June while Aureobasidium spp. and other nonidentified yeast were recovered at higher rates later in the growing season. Propagules of Alternaria spp. were recovered on PDA-F500 and MSM but not on APDA-F500 during the three sampling periods. There was a significant $(P=0.017)$ reduction in recovery of bacteria on APDA-F500 compared with PDA-F500 and on MSM, despite the high concentration of streptomycin $(1,000 \mu \mathrm{g} / \mathrm{ml})$ in the later medium (Table 5). The slow growth of $M$. fructicola propagules on MSM made its distinction from other contami-

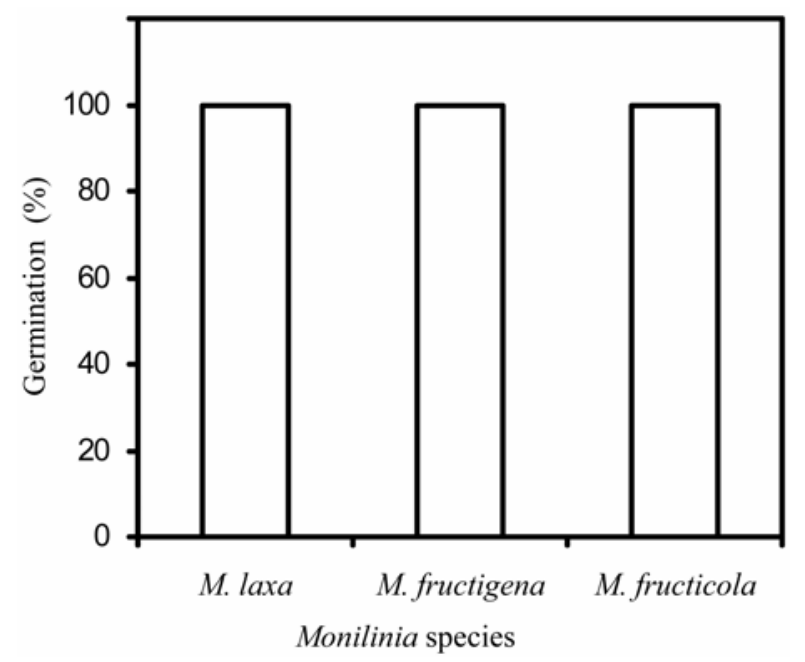

Fig. 3. Germination of three Monilinia spp. on acidified potato dextrose agar amended with fosetyl-aluminum at $500 \mu \mathrm{g} / \mathrm{ml}$ relative to unamended potato dextrose agar after $72 \mathrm{~h}$. Data are the means of 36 replicates (two isolates per species $\times$ three plate $\times$ three countings per plate) across two experimental runs. nants more difficult compared with APDA-F500 and PDA-F500 (Fig. 4). Other common fungi isolated from peach surfaces included $R$. stolonifer and Geotrichum candidum (on PDAF500 only), Fusarium equiseti, Ustilago esculenta, Epicoccum nigrum, Rhizosphaera macrospora, and the yeast Issatchenkia orientalis.

\section{DISCUSSION}

The recovery of Monilinia spp. from plants is an important step for studying their biology and ecology, but isolation attempts can be challenging. Bacteria and yeasts are generally faster growing, omnipresent on fruit surfaces, and tend to develop suppressive or antagonistic activities against fungi. Additionally, other fastgrowing fungi can overgrow the target fungus during isolation and culturing. MSM was previously developed for the recovery of Monilinia spp. from stone fruits (49) but, in this study, MSM was suppressive to mycelial growth of M. fructicola. MSM also did not prevent germination of three of the eight common peach fungal contaminants tested in this study, including Penicillium expansum, Phomopsis amygdali, and Aspergillus niger. The weak selectivity shown in this study is in agreement with an earlier report stating that growth of Monilinia spp. on MSM can be obscured by bacteria, yeast, and other fungi, especially when free water is present on the medium surface when plating the sample (49). With the new selective medium APDA-F500 developed in this study, the recovery of Monilinia spp. from stone fruit is much improved. Many potential fungal contaminants were suppressed while Monilinia colonies were still developing.

We examined four antifungal agents, including 2-dD-glucose, ammonium molybdate, dichloran, and fosetyl-Al. These agents

TABLE 4. Mycelial growth of Monilinia spp. isolates from different geographic origins and hosts on acidified potato dextrose agar amended with fosetyl-Al at $500 \mu \mathrm{g} / \mathrm{ml}$

\begin{tabular}{|c|c|c|}
\hline Species, isolate & Geographic origin & Relative growth $(\%)^{\mathrm{a}}$ \\
\hline \multicolumn{3}{|c|}{ Monilinia fructicola } \\
\hline Mf.Pdt11 & South Carolina, United States & $49.7 \pm 9.8$ \\
\hline Mf.DMap4 & South Carolina, United States & $63.3 \pm 7.5$ \\
\hline Mf.Egpc5 & South Carolina, United States & $48.1 \pm 7.0$ \\
\hline Mf.Egpc12 & South Carolina, United States & $56.6 \pm 13.5$ \\
\hline Mf.Bmpc9 & Georgia, United States & $75.6 \pm 13.6$ \\
\hline Mf.Bpc1 & Georgia, United States & $58.1 \pm 13.7$ \\
\hline Mf.Bpc8 & Georgia, United States & $52.4 \pm 13.8$ \\
\hline Mf.SLf1 & Georgia, United States & $83.3 \pm 13.5$ \\
\hline 139 & California, United States & $69.1 \pm 11.6$ \\
\hline NJ07 & New Jersey, United States & $81.8 \pm 9.7$ \\
\hline NJ08 & New Jersey, United States & $52.2 \pm 6.1$ \\
\hline NJ012 & New Jersey, United States & $57.7 \pm 6.8$ \\
\hline NJ015 & New Jersey, United States & $46.5 \pm 3.9$ \\
\hline $2 \mathrm{~F}$ & New York, United States & $45.8 \pm 5.7$ \\
\hline $6 c$ & New York, United States & $76.6 \pm 13.5$ \\
\hline $10 \mathrm{~B}$ & New York, United States & $48.6 \pm 10.1$ \\
\hline $13 \mathrm{~B}$ & New York, United States & $53.9 \pm 12.7$ \\
\hline \multicolumn{3}{|l|}{ M. fructigena } \\
\hline MFG.E4 & Szabolcs, Hungary & $78.8 \pm 2.5$ \\
\hline MFG.D10 & Hajdú, Hungary & $77.4 \pm 2.2$ \\
\hline MFG.BP7 & Pest, Hungary & $58.8 \pm 6.4$ \\
\hline MFG.ME16 & Borsod, Hungary & $65.6 \pm 10.6$ \\
\hline MFG.MA11 & Szabolcs, Hungary & $63.2 \pm 5.4$ \\
\hline MFG.DP24 & Hajdú, Hungary & $80.4 \pm 6.8$ \\
\hline \multicolumn{3}{|l|}{ M. laxa } \\
\hline ML.E14 & Szabolcs, Hungary & $71.7 \pm 3.1$ \\
\hline ML.D5 & Hajdú, Hungary & $73.5 \pm 3.2$ \\
\hline ML.BP5 & Pest, Hungary & $54.6 \pm 11.3$ \\
\hline ML.ME6 & Borsod, Hungary & $69.0 \pm 5.9$ \\
\hline ML.MA21 & Szabolcs, Hungary & $53.3 \pm 9.4$ \\
\hline ML.DP7 & Hajdú, Hungary & $79.8 \pm 4.8$ \\
\hline
\end{tabular}

${ }^{\text {a }}$ Relative growth relative to unamended potato dextrose agar after $96 \mathrm{~h}$ of incubation at $22^{\circ} \mathrm{C}$. Data are the mean of 10 replicate petri dishes across two experimental runs. 


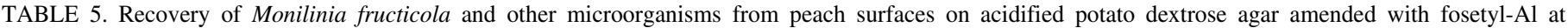
$500 \mu \mathrm{g} / \mathrm{ml}$ (APDA-F500) (pH 3.6), potato dextrose agar amended with fosetyl-Al at $500 \mu \mathrm{g} / \mathrm{ml}$ (PDA-F500), and Monilinia selective medium (MSM)

\begin{tabular}{|c|c|c|c|c|c|c|c|c|c|}
\hline \multirow[b]{3}{*}{ Organism } & \multicolumn{9}{|c|}{ Mean number of colonies per square centimeter of fruit surface $\pm \mathrm{SD}^{\mathrm{a}}$} \\
\hline & \multicolumn{3}{|c|}{6 June } & \multicolumn{3}{|c|}{9 July } & \multicolumn{3}{|c|}{13 August } \\
\hline & APDA-F500 & PDA-F500 & MSM & APDA-F500 & PDA-F500 & MSM & APDA-F500 & PDA-F500 & MSM \\
\hline Monilinia fructicola & 0 & 0 & 0 & $5 \pm 0.8$ & $8 \pm 1.2$ & 0 & $76 \pm 6.8$ & $99 \pm 9.8$ & $8 \pm 0.4$ \\
\hline Aureobasidium spp. & $7 \pm 1.2$ & $19 \pm 1.6$ & $13 \pm 1.4$ & $8 \pm 1.1$ & $7 \pm 1.2$ & $8 \pm 1.4$ & $7 \pm 1.9$ & $2 \pm 0.2$ & $2 \pm 0.8$ \\
\hline Cladosporium spp. & $12 \pm 2.3$ & $103 \pm 7.1$ & $109 \pm 14.7$ & $2 \pm 0.9$ & $4 \pm 0.9$ & $23 \pm 0.8$ & $2 \pm 0.8$ & $2 \pm 0.8$ & $2 \pm 0.6$ \\
\hline Alternaria spp. & 0 & $19 \pm 2.5$ & $12 \pm 2.0$ & 0 & $1 \pm 0.3$ & $9 \pm 0.2$ & 0 & $3 \pm 0.3$ & $12 \pm 1.2$ \\
\hline Bacteria & $3 \pm 0.8$ & $72 \pm 9.0$ & $27 \pm 4.2$ & $1 \pm 0.4$ & $185 \pm 8.5$ & $34 \pm 4.5$ & $3 \pm 0.4$ & $35 \pm 8.1$ & $17 \pm 1.9$ \\
\hline Yeast & $5 \pm 1.2$ & $12 \pm 2.3$ & $93 \pm 14.3$ & $12 \pm 2.9$ & $24 \pm 3.2$ & $156 \pm 8.3$ & $20 \pm 2.1$ & $31 \pm 3.3$ & $71 \pm 1.9$ \\
\hline Other & $2 \pm 0.4$ & $7 \pm 1.4$ & $1 \pm 0.2$ & $2 \pm 0.4$ & $1 \pm 0.5$ & 0 & $3 \pm 0.4$ & $26 \pm 3.2$ & $4 \pm 0.9$ \\
\hline Total contaminants & $29 \pm 1.2$ & $232 \pm 4.3$ & $254 \pm 6.1$ & $25 \pm 1.1$ & $222 \pm 2.4$ & $230 \pm 2.4$ & $35 \pm 1.1$ & $99 \pm 2.7$ & $108 \pm 1.1$ \\
\hline M. fructicola $(\%)$ & 0 & 0 & 0 & 16.6 & 3.5 & 0 & 69.1 & 50.0 & 6.8 \\
\hline
\end{tabular}

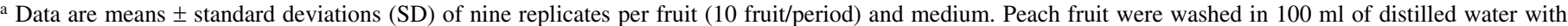
$0.05 \%$ Tween 80 and a 100- $\mu$ l aliquot of each fruit-wash was spread over media. Propagules of Monilinia and other microorganisms were counted on each dish after 4 days of incubation at $22^{\circ} \mathrm{C}$ using a digital colony counter and expressed in number of colonies per square centimeter of fruit surface.

TABLE 6. Recovery of Monilinia fructigena, M. laxa, and other microorganisms from peach and plum surfaces on acidified potato dextrose agar amended with fosetyl-aluminum at $500 \mu \mathrm{g} / \mathrm{ml}$ (APDA-F500) (pH 3.6)

\begin{tabular}{lcc}
\hline & \multicolumn{2}{c}{ Mean number of colonies/cm ${ }^{2}$ fruit surface $\pm \mathrm{SD}^{\mathrm{a}}$} \\
\cline { 2 - 3 } Organism & Peach & Plum \\
\hline Monilinia fructigena & $116.5 \pm 22$ & $53.7 \pm 8.1$ \\
Monilinia laxa & $7.5 \pm 2.3$ & $2.9 \pm 2.2$ \\
Aureobasidium spp. & $10.2 \pm 3.3$ & $2.0 \pm 1.4$ \\
Cladosporium spp. & $11.3 \pm 2.6$ & $8.5 \pm 2.9$ \\
Alternaria spp. & 0 & 0 \\
Bacteria & $9.3 \pm 2.9$ & $7.2 \pm 3.4$ \\
Yeast & $16.9 \pm 5.2$ & $14.4 \pm 4.1$ \\
Other & $9.1 \pm 2.9$ & $6.9 \pm 2.2$ \\
Total contaminants & $31.5 \pm 6.3$ & $40.8 \pm 6.6$ \\
M. fructigena $(\%)$ & 64.3 & 56.2 \\
M. laxa $(\%)$ & 4.2 & 3.0
\end{tabular}

a Data are means \pm standard deviations (SD) of nine replicate plantings per fruit. In total, 20 plum and 20 peach fruit were sampled on 16 and 29 August 2008, respectively.

were chosen because of their suppressive activity against some common peach fruit pathogens and contaminants. The sugar analog 2-dD-glucose was reported to reduce the mycelial growth of Rhizopus stolonifer, Botrytis cinerea, and Penicillium expansum at $1 \mathrm{mg} / \mathrm{ml}$ without completely inhibiting M. fructicola (15). In this study, both germination and mycelial growth of $M$. fructicola were completely inhibited at a much lower concentration $(5 \mu \mathrm{g} / \mathrm{ml})$, whereas germination of most other fungi tested was not inhibited. Similarly, ammonium molybdate showed activity against Penicillium expansum $(37,44,46)$ and $R$. stolonifer (44) but also inhibited germination and mycelial growth of M. fructicola in the present study. Additionally, ammonium molybdate at $5 \mathrm{mM}$ enhanced the biocontrol activity of yeasts against $M$. fructicola on sweet cherry (50). Dichloran (2,6-dichloro-4-nitroaniline) formulated as Botran 75WP is a protectant fungicide, recommended for pre- and postharvest Rhizopus rot control in stone, berry, and grape fruit. Dichloran was reported to inhibit $R$. stolonifer and Aspergillus spp. at $2.5 \mu \mathrm{g} / \mathrm{ml}$ and Penicillium spp. at $12.5 \mu \mathrm{g} / \mathrm{ml}$ when added to a minimum medium (33). We confirmed the activity of dichloran against $R$. stolonifer but also noticed an inhibitory effect against $M$. fructicola at low concentrations. Dichloran was less active against mycelial growth of Alternaria alternata, Phomopsis amygdali, and Penicillium expansum and did not affect conidial germination of these organisms. Among other potential fungal growth suppressors evaluated, rose bengal, ammonium sulfate, sodium moybdate dehydrate, and ziram were either suppressive of Monilinia spp. growth or with no effect against the other fungal contaminants (data not shown).
Compared with the three other active ingredients investigated, fosetyl-Al was the most suitable selective agent for the development of a new Monilinia spp.-selective medium. The fungicide fosetyl-Al amended to fenaminousulf medium at $250 \mu \mathrm{g} / \mathrm{ml}$ was previously recommended for selective isolation of Rhizoctonia solani from soil (20). In this study, fosetyl-Al alone failed to inhibit germination and mycelial growth of any of the fungi tested but reduced sporulation at the higher concentration $(>750 \mu \mathrm{g} / \mathrm{ml})$, with the exception of $M$. fructicola. The acidification of fosetylAl-amended PDA to $\mathrm{pH} 3.2$ to 3.6 resulted in germination and mycelial growth inhibition of all of the seven test fungi but $M$. fructicola in vitro. Germination of Monilinia spp. isolates originating from different geographic locations was not inhibited on APDA-F500, and little variation in mycelial growth inhibition was observed. Therefore, APDA-F500 selectively supports growth of different genotypes of the three most common Monilinia spp., assuming that isolates from different locations are genetically diverse. At pH 3.2 and 3.6, APDA-F500 limited the growth of contaminants effectively while supporting $M$. fructicola development during isolation. The Monilinia spp.-selective properties of APDA-F500 were confirmed on stone fruits from Hungary, documenting the successful recovery of $M$. fructigena and $M$. laxa under different environmental conditions. Acidification of PDA helped suppress bacterial growth, which is consistent with earlier reports $(1,27,34)$, and also inhibited key fungal contaminants at $\mathrm{pH} 3.2$.

Fosetyl-Al belongs to the chemical group known as phosphonates and its activity has been reported against several fungi, including a range of Phytophthora spp. $(12,47)$. Numerous studies on the mode of action of phosphonates have identified alteration of fungal metabolism $(5,52)$ and changes in cell morphology $(29,30)$. It was also suggested that a perturbation of phosphorous metabolism in fungi may affect their sensitivity to phosphonates $(23,51)$. Lowering the $\mathrm{pH}$ increased the fungicidal activity of fosetyl-Al. It is possible that the change of the $\mathrm{H}^{+}$gradient in the acidified medium may have affected the fungal membrane permeability for fosetyl-Al of most tested fungi but to a lesser degree for Monilinia spp. This would be consistent with findings by Barchietto et al. (6) showing that, at a stable $\mathrm{pH}$, the uptake of fosetyl-Al can be different from one fungus to another. For example, the activity of fosetyl-Al against Phytophthora nicotianae was shown to be higher at $\mathrm{pH}$ values of 4 to 7 (22), whereas its activity was not $\mathrm{pH}$ related against $P$. palmivora (41).

The new APDA-F500 medium is suitable for inoculum density determination on stone fruit surfaces, which may aid in the prediction of preharvest brown rot disease pressure. The inhibition of bacteria and selective reduction of fungal growth resulted in small, easily distinguishable, and countable Monilinia colonies. Propagule counts on APDA-F500 revealed a progressive buildup 

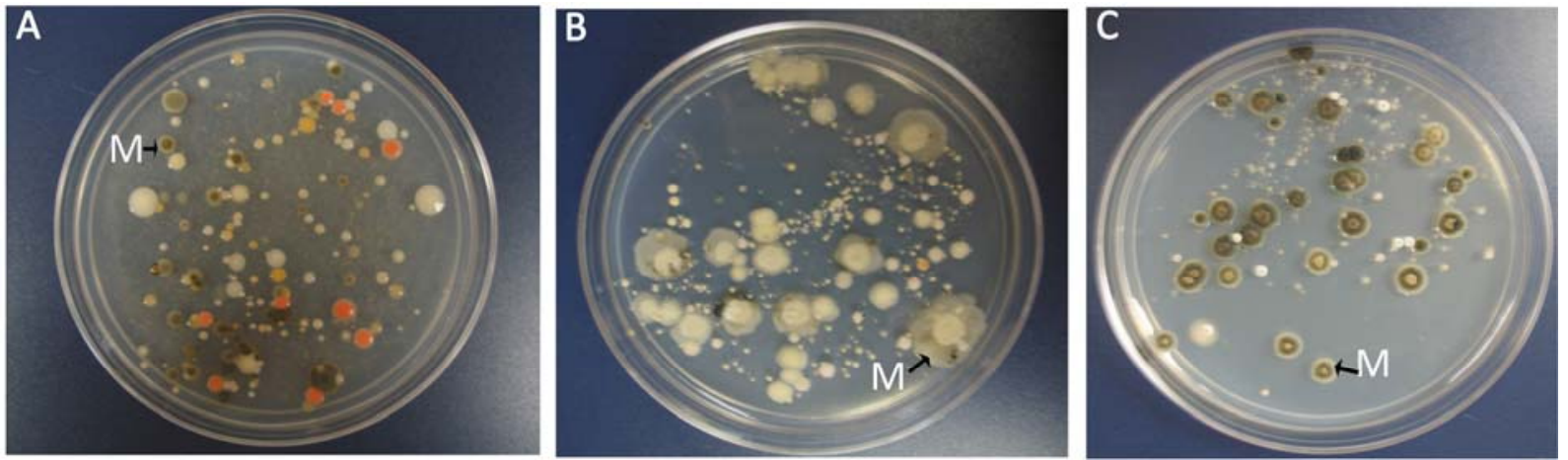

Fig. 4. Growth and colony morphology of Monilinia fructicola and other organisms washed off from peach fruit (cv. Contender) on A, Monilinia spp.-selective medium (MSM) ; B, potato dextrose agar (PDA) amended with fosetyl-aluminum (fosetyl-AL) at $500 \mu \mathrm{g} / \mathrm{ml}$; and $\mathbf{C}$, acidified PDA amended with fosetyl-Al at $500 \mu \mathrm{g} / \mathrm{ml}, \mathrm{pH} 3.6$, after 4 days of incubation at $22^{\circ} \mathrm{C}$. M indicates $M$. fructicola propagules.

of M. fructicola on peach fruit from South Carolina as summer progressed, which is consistent with earlier studies $(16,38,49)$. The highest density of M. fructicola propagules on peach fruit was found at the August sampling date. A comparable density of M. fructigena propagules was found on peach and plum fruit collected in August in Hungary. The low density of M. laxa population on fruit surfaces from Hungary may be explained by the epidemiology of this species. M. laxa causes primarily blossom blight and is a minor fruit rot pathogen in Hungary on plum and peach (24). On the other hand, M. fructigena has not been reported to cause blossom infections in Central Europe. This species occurs primarily on ripening fruit and can cause significant fruit brown rot, especially on fruit with severe insect damage (25).

In summary, APDA-F500 was found to be a suitable medium for selective isolation of Monilinia spp. from stone fruit. This medium suppressed bacteria and inhibited or limited the growth of fungi and other organisms commonly encountered on stone fruit. APDA-F500 also yielded comparable recovery rates of Monilinia spp. of stone fruit under different environmental conditions. APDA-F500 will facilitate Monilinia spp. recovery from stone fruits and will be a useful tool for the study of the biology, epidemiology, and quantification of Monilinia propagules as part of disease management efforts.

\section{ACKNOWLEDGMENTS}

Technical contribution no. 5559 of the Clemson University Experimental Station. This material is based upon work supported by CSREES/USDA under project number SC-1000642 and funded in part by the USDA-CSREES S-RIPM grant no. 2006-34103-17007, a grant of the Hungarian Scientific Research Fund (grant no. HSRF 78339), and a János Bolyai Research Fellowship, Hungary. We thank M. Hotchkiss, USDAARS, Byron, GA, for providing the R. stolonifer isolates; and Kerik D. Cox, Cornell University, Geneva, NY, Norman Lalancette, Rutgers Agricultural Research and Extension Center, Bridgeton, NJ, and Themis J. Michailides, University of California, Davis, for providing some of the M. fructicola isolates used in this study.

\section{LITERATURE CITED}

1. American Public Health Association. 1978. Standard Methods for the Examination of Dairy Products, 14th ed. American Public Health Association Inc. Washington, DC.

2. Amiri, A., and Bompeix, G. 2005. Diversity and population dynamics of Penicillium spp. on apples in pre- and postharvest environments: Consequences for decay development. Plant Pathol. 54:74-81.

3. Amiri. A., Scherm, H., Brannen, P. M, and Schnabel, G. 2008. Laboratory evaluation of three rapid, agar-based assays to assess fungicide sensitivity in Monilinia fructicola. Plant Dis. 92:415-420.

4. Andrews, J. H., Kinkel, L. L., Berbee, F. M., and Nordheim, E. V. 1987. Fungi leaves and the theory of island biogeography. Microbiol. Ecol. 14:277-290.
5. Barchietto, T., Saindrenan, P., and Bompeix, G. 1988. Characterization of phosphonate uptake in two Phytophthora spp. and its inhibition by phosphate. Arch. Microbiol. 151:54-58.

6. Barchietto, T., Saindrenan, P., and Bompeix, G. 1992. Physiological responses of Phytophthora citrophtora to a subinhibitory concentration of phosphonate. Pestic. Chem. Physiol. 42:151-166.

7. Batra, L. R. 1991. World species of Monilinia (fungi): their ecology, biosystematics and control. Mycologia Memoir No. 16. J. Cramer, Berlin.

8. Biggs, A. R., and Northover, J. 1988. Early and late-season susceptibility of peach fruits to Monilinia fructicola. Plant Dis. 72:1070-1074.

9. Bosshard, E., Hilber-Bodmer, M., Schärer, H. J., Bünter, M., and Duffy, B. 2006. First report of quarantine brown rot pathogen Monilinia fructicola on imported stone fruits in Switzerland. Plant Dis. 90:1554.

10. Byrde, R. J. W., and Willets. H. J. 1977. The Brown Rot Fungi of Fruit: Their Biology and Control. Pergamon Press, Oxford.

11. Cohen, G. 1994. The earth is round $(P<0.05)$. Am. Psychol. 49:9971003.

12. Darakis, G. A., Bourbos, V. A., and Skoudridakis, M. T. 1997. Phosphonate transport in Phytophthora capsici. Plant Pathol. 46:762-772.

13. Duchoslavová, J., Širucková, I., Zapletalová, E., Navrátil, M., and Šafárová, D. 2007. First report of brown rot caused by Monilinia fructicola on various stone and pome fruits in the Czech Republic. Plant Dis. 91:907.

14. Edwards, S. G., and Seddon, B. 2001. Selective media for the specific isolation and enumeration of Botrytis cinerea conidia. Lett. Appl. Microbiol. 32:63-66.

15. El Ghaout, A., Wilson, C. L., and Wisniewski, M. 1995. Sugar analogs as potential fungicides for postharvest pathogens of apple and peach. Plant Dis. 79:254-258

16. Emery, K. M., Michailides, T. J., and Scherm, H. 2000. Incidence of latent infection of immature peach fruit by Monilinia fructicola and relationship to brown rot in Georgia. Plant Dis. 84:853-857.

17. Fairchild, E. J., Lewis, R. S., and Taken, R. L. 1977. Registry of Toxic Effects of Chemical Substances. U. S. Department of Health, Education and Welfare, Cincinnati.

18. Fenn, M. E., and Coffey, M. D. 1984. Studies on the in vitro and in vivo antifungal activity of fosetyl-Al and phosphorous acid. Phytopathology 74:606-611.

19. Frisvad, J. C. 1981. A selective and indicative medium for groups of Penicillium viridicatum producing different mycotoxins in cereal. J. Appl. Bacteriol. 54:409-416.

20. Gangopadhyay, S., and Grover, R. K. 1985. A selective medium for isolating Rhizoctonia solani from soil. Ann. Appl. Biol. 106:405-412.

21. Gell, I., De Cal, A., Torres, R., Usall, J., and Melgarejo, P. 2008. Relationship between the incidence of latent infections caused by Monilinia spp. and the incidence of brown rot of peach fruit: factors affecting latent infection. Eur. J. Plant Pathol. 121:487-498.

22. Guest, D. I. 1984. The influence of cultural factors on the direct antifungal activities of fosetyl-Al, propamocarb, metalaxyl, SN 75196 and dowco 444. Phytopathol. Z. 111:155-164.

23. Guest, D. I., and Grant, B. R. 1991. The complex action of phosphonates as antifungal agents. Biol. Rev. 66:159-187.

24. Holb, I. J. 2003. Analyses of temporal dynamics of brown rot development on fruit in organic apple production. Int. J. Hortic. Sci. 9:97100.

25. Holb, I. J., and Scherm, H. 2008. Quantitative relationships between different injury factors and development of brown rot caused by Monilinia fructigena in integrated and organic apple orchards. Phytopathology 98:79-86. 
26. Honey, E. E. 1928. The monilioid species Sclerotinia. Mycologia 20:127157.

27. Hong, C. X., Michailides, T. J., and Holtz, B. A. 2000. Mycoflora of stone fruit mummies in California orchards. Plant Dis. 84:417-422.

28. Hong, S. G., and Pryor, B. M. 2004. Development of selective media for the isolation and enumeration of Alternaria species from soil and plant debris. Can. J. Microbiol. 50:461-468.

29. Jiang, Y. 1990. Alternations in the host-parasite interface between Phytophthora infestans and tomato leaf cells after treatment with fosetylAl. Plant Sci. 71:267-276.

30. Jiang, Y., and Grossman, F. 1992. Subcellular alternations in Phytophthora infestans infecting tomato leaves treated with fosetyl-A1. Pestic. Biochem. Physiol. 44:226-238.

31. Kwasna, H., Ward, E., and Bateman, G. L. 2006. Phylogenetic relationship among zygomycetes from soil base on ITS1/2 rDNA sequences. Mycol. Res. 110:501-510.

32. Kerssies, A. 1990. A selective medium for Botrytis cinerea to be used in a spore-trap. Neth. J. Plant Pathol. 96:247-250.

33. King, A., Hocking, A. D., and Pitt, I. J. 1979. Dichloran-rose bengal medium for enumeration and isolation of molds from foods. Appl. Environ. Mircobiol. 37:959-964.

34. Koburger, J. A. 1976. Yeasts and molds. Pages 225-229 in: Compendium of Methods for the Microbiological Examination of Foods. M. L. Speck, ed. American Public Health Association Inc., Washington, DC.

35. Landgraf, F. A., and Zehr, E. 1982. Inoculum sources of Monilinia fructicola in South Carolina peach orchards. Phytopathology 72:185-190.

36. Larena, I., Torres, R., De Cal, A., Liñan, M., Melgarejo, P., and Domenichini, P. 2005. Biological control of postharvest brown rot (Monilinia spp.) of peaches by field applications of Epicoccum nigrum. Biol. Control 32:305-310.

37. Lima, G., Spina, A. M., Castoria, R., De Curtis, F., and De Cicco, V. 2005. Integration of biocontrol agents and food-grade additives for enhancing protection of stored apples from Penicillium expansum. J. Food Prot. 68:2100-21006.

38. Luo, Y., Michailides, T. J., Morgan, D. P., Krueger, W. H., and Buchner, R. P. 2005. Inoculum dynamics, fruit infection, and development of brown rot in prune orchards in California. Phytopathology 95:1132-1136.

39. Ma, Z., Yoshimura, M. A., and Michailides, T. J. 2003. Identification and characterization of benzimidazole resistance in Monilinia fructicola from stone fruit orchards in California. Appl. Environ. Microbiol. 29:71457152.

40. Malvárez, G., Rodriguez, A., Aguilar, C., Silveira, A. C., Silvera, E., Burgueño, J., and Mondino, P. 2004. Monilinia fructicola, the only Monilinia species currently causing brown rot of peach (Prunus persica) in Uruguay. Fitopatologia 39:126-132.

41. Martin, H., Grant, B. R., and Stehmann, C. 1998. Inhibition of organic pyrophosphate by phosphonate-a site of action in Phytophthora spp.
Pestic. Biochem. Physiol. 61:65-77.

42. Matsumuto, M., Aiso, S., Senoh, H., Yamazaki, K., Arito, H., Nagano, K., Yamamoto, S., and Matsushima, T. 2006. Carcinogenicity and chronic toxicity of para-chloronitrobenzene in rats and mice by two-year feeding. J. Environ. Pathol. Toxicol. Oncol. 25:571-584.

43. Nash, S. M., and Snyder, W. C. 1962. Quantitative estimations by plate counts of propagules of bean root rot Fusarium in field soils. Phytopathology 52:567-572.

44. Nunes, C., Usall, J., Teixidó, N., de Eribe, X. O., and Viñas, I. 2001. Control of post-harvest decay of apples by pre-harvest and post-harvest application of ammonium molybdate. Pest Manage. Sci. 57:1093-1099.

45. Ogawa, J. M., and English, H. 1991. Diseases of Temperate Zone Tree Fruit and Nut Crops. Publ. 3345. University of California, Division of Agriculture and Natural Resources, Oakland.

46. Palou, L., Usall, J., Smilanick, J. L., Aguilar, M. J., and Viñas, I. 2002. Evaluation of food additives and low-toxicity compounds as alternative chemicals for the control of Penicillium digitatum and Penicillium italicum on citrus fruit. Pest Manage. Sci. 58:459-466.

47. Panicker, S., and Gangadharam, K. 1999. Controlling downy mildew of maize caused by Peronosclerospora sorghi by foliar sprays of phosphonic acid compounds. Crop Prot. 18:115-118.

48. Petróczy, M., and Palkovics, L. 2006. First report of brown rot caused by Monilinia fructicola on imported peach in Hungary. Plant Dis. 90:375.

49. Phillips, D. J., and Harvey, J. M. 1975. Selective medium for detection of inoculum of Monilinia spp. on stone fruits. Phytopathology 65:12331236.

50. Qin, G. Z., Tian, S. P., Xu, Y., Chan, Z. L., and Li, B. Q. 2006. Combination of antagonist yeasts with two food additives for control of brown rot caused by Monilinia fructicola on sweet cherry fruit. J. Appl. Microbiol. 100:508-515.

51. Saindrenan, P., Barchietto, T., and Bompeix, G. 1990. Effect of phosphonate on the elicitor activity of culture filtrates of Phytophthora cryptogea. Plant Sci. 67:245-251.

52. Smillie, R. H., Dunstan, R. H., Grant, B. R., Grifith, J. M., Iser, J., and Niere, J. O. 1990. The mode of action of antifungal agent phosphate. OEPP/EPPO Bull. 20:185-192.

53. Takehara, T., Kuniyasu, K., Mori, M., and Hagiwara, H. 2003. Use of nitrate-nonutilizing mutant and selective media to examine population dynamics of Fusarium oxysporum f. sp. spinaciae in soil. Phytopathology 93:1173-1181.

54. Tian, S. P., and Bertolini, P. 1999. Effect of temperature during conidial formation of Monilinia laxa on conidial size, germination and infection of stored nectarines. Phytopathol. Z. 147:635-641.

55. Vujanovic, V., Hamel, C., Jabaji-Hare, S., and St.-Arnaud, M. 2002. Development of a selective myclobutanil agar (MBA) medium for the isolation of Fusarium species from asparagus fields. Can. J. Microbiol. 48:841-847. 